IRA-International Journal of Management \&

Social Sciences

ISSN 2455-2267; Vol.11, Issue 03 (June 2018)

Pg. no. 118-127.

Institute of Research Advances

http://research-advances.org/index.php/RAJMSS

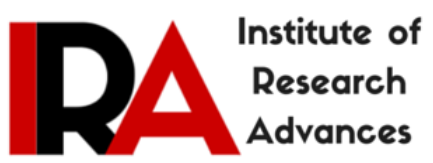

\title{
50 Years of Naxalite Movement and Telugu Cinema: A Content Analysis
}

\author{
Dr. J. Madhu Babu ${ }^{1 \#}$ \& S. Sowjanya Babu ${ }^{2}$ \\ ${ }^{1}$ Assistant Professor, Dept. Of Journalism and Mass Communication, Acharya Nagarjuna University, Guntur, \\ Andhra Pradesh, India. \\ ${ }^{2}$ Research Scholar, Dept. Of Journalism and Mass Communication, Acharya Nagarjuna University, Guntur, \\ Andhra Pradesh, India. \\ \#corresponding author. \\ Type of Review: Peer Reviewed. \\ DOI: http://dx.doi.org/10.21013/jmss.v11.n3.p2
}

How to cite this paper:

Babu, J.M., Babu, S.S. (2018). 50 Years of Naxalite Movement and Telugu Cinema: A Content Analysis. IRA-International Journal of Management \& Social Sciences (ISSN 2455-2267), 11(3), 118-127. doi:http://dx.doi.org/10.21013/jmss.v11.n3.p2

(C) Institute of Research Advances.

\section{(cc)) BY-NO}

This work is licensed under a Creative Commons Attribution-Non Commercial 4.0 International License subject to proper citation to the publication source of the work.

Disclaimer: The scholarly papers as reviewed and published by the Institute of Research Advances (IRA) are the views and opinions of their respective authors and are not the views or opinions of the IRA. The IRA disclaims of any harm or loss caused due to the published content to any party.

Institute of Research Advances is an institutional publisher member of Publishers Inter Linking Association Inc. (PILA-CrossRef), USA. The institute is an institutional signatory to the Budapest Open Access Initiative, Hungary advocating the open access of scientific and scholarly knowledge. The Institute is a registered content provider under Open Access Initiative Protocol for Metadata Harvesting (OAI-PMH).

The journal is indexed \& included in WorldCat Discovery Service (USA), CrossRef Metadata Search (USA), WorldCat (USA), OCLC (USA), Open J-Gate (India), EZB (Germany) Scilit (Switzerland), Airiti (China), Bielefeld Academic Search Engine (BASE) of Bielefeld University, Germany, PKP Index of Simon Fraser University, Canada. 


\begin{abstract}
The Naxalite movement has influenced Indian cinema since the 1970s in different forms and degree. It has also left some valuable imprints on the cinema. A number of films in different languages have been made on themes of Naxalite movement directly or indirectly. Last year, Naxalite movement has completed50 years. In this context the researchers took at the four Telugu films i.e. Sindhooram (1997), Encounter (1997), Kubusam(2002), and Virodhi(2011).In an appreciation of how a Psychological approach to the story can highlight the dynamics of emotional cinematic experience, this study presents a critical analysis of these four films.
\end{abstract}

Key words: Naxalite movement, Telugu Cinema, Maoists

\title{
An Overview
}

All the films made on Naxalism focus, broadly, on the resistance against social inequality, corruption, poverty, injustice associated socio- economic evils for creation of a just society based on democratic principles. The negative aspects of such films are noticeable, when film-makers and directors try to present it in distorted forms. While, mixing romanticism and other orientations for commercial purposes and not intending to highlight the naked reality of the Indian society that the Naxalite movement focuses on.

The Naxalite Movement derives its name from a small village Naxallbari on the tri junction of India, Nepal and East Pakistan (Presently Bangladesh). The Movement owes its origin to the Communist Party of India (Marxist) in West Bengal. Naxalism is fight against poverty and alienation. Naxalite paved the way for waging struggles against the established feudal orders by the oppressed masses in different parts of the Country. Two Communist leaders - Charu Mazumdar and Kanu Sanyal ignited the first spark of Naxalite movement to achieve peasant rights at Naxalbari in West Bengal. The first clash was triggered between peasants and landed gentry on May 22, 1967 when a landlord attempted to forcibly evict a poor tenant from his land. This incident received unprecedented publicity in the national press. The rich peasant parties, particularly the Bangala Congres, the Praja Socialist Party (PSP) and the Samyukta Socialist Party as well as the Congress Party demanded immediate police action and they took initiative in forming 'Resistance Committees'. Within few days, three Tribal were killed by the 'defensive actions' of these Committees.

In the year $1968-69$, saw the outbreak of struggles of landless and poor peasants that rebelled against the rich people. The upsurge in Naxalbari had its impact in Srikakulam in the state of Andhra Pradesh. In this District, two school teachers built up a mass base amongst the tribal since the late 1950s. Vempatapu Satyanarayana (Popularly known as Satyam) together with Adibhatla Kailasam was finding the militancy of their struggle coming in to direct conflict with the existing Communist Party state leadership (Madhu Babu.J. 2010).

The Naxalites also organized Praja Courts (People's Courts) to dispense with instant justice. People's Court become the main instrument not only for solving the economic problems of the exploited classes but also deal with legal matters, family disputes, corruption in administration and dowry harassment cases. The Movement took a new turn in October, 1968 after an incident in Garudabhadra, in which a demonstration of tribal people was attacked by the men of landlords. As per the advice of the Mujumdar, the Srikakulam leaders to forsake the line of building mass movements based on economic struggles and to start guerilla actions. The first phase of the guerilla movement began on November 25, 1968, when 250 tribal people from 25 villages attacked the houses of a moneylender in Parvathipuram and took over his accumulated rice and grains worth of 20,000. Alongside these activities there took place several encounters with the police.

\section{Splits and Merges}

The Communist Movement in India split several times in the 1960s, and a major feature of these splits was the role, the attitude and views of the Communist party of China. The first split, 1964, led to the information of CPI (M), the second, in 1967, led to the birth of the Naxalite movement and CPI (ML), subsequently, the CPI (ML) split into smaller groups because of conflicting interpretations of the Chinese line. In this line caused further splits with leaders such as Kondapalli Seethramaiah (Andhra Pradesh) and Prasad (Bihar) dissociating themselves from the 
activities of the party. Prasad formed CPI (ML) (unity organization) Kondapalli Seetharamaiah started the CPI (ML) - People's War on April 22, 1980.

The Maoist Communist Centre of India (MCC) and the CPI (ML) People's War merged to form a new entity, the Communist Party of India - Maoist (CPI-Maoist) on September 21, 2004.

\section{Marxist theory on Films}

The concept of Marxism by the medium of cinema. It was founded by Sergei Eisentein, and supported by French Marxist filmmaker Jean- Luc Godarad and situationist movie maker Guy Debord. A Marxist critic will attempt to associate character and events in a film as representative of class struggle, labor vs management, poor vs rich, oppressive Governments and other Marxist socio political concerns.

The year 1968 marks a shift to a different model of politics than traditional Marxist politics - postmodern politics. The year 1968 is also an important date in the history of cinema especially French and European cinema, because during this moment filmmakers became as politically active as never before, perhaps with the exception of the period following the October Revolution.

Film makers of this moment wanted to make films for people who would see themselves on screen, often literally, by filming strikes and employing nonprofessional actors, films can be made on a very low budget and cinema became intermingled with political activism. According to Godard, making films politically in the western context means using independent financial sources, rather than being backed by large companies, which are profit oriented. The requirement of producing political film politically results from the conviction that every film made within a capitalist framework ultimately serves capitalism. In particular, some films sponsored by capitalist might encourage viewers to think seriously about the injustice of the capitalist clause system and this way make a contribution to the struggle for human emancipation. This approach is reflected in recent scholarship focusing on Marxist motive in the films of James Cameron (Kendrik, 1999) and Wachouski Siblings (Burns, 2015).

\section{Review of Literature}

Between 1967 and 1970, subject matter remained primarily rural. Writers talked about zamindaris, moneylenders, and the revisionist character of the other communist party leaders. After 1970, the conflict shifted towards urban areas and the enemy became the police, CPI (M), and Congress party members. From 1970-71 the city and suburbs witnessed the mass killings of alleged Naxalites. Much of Naxalite literature feature prominent female characters, not only as mothers, sisters or lovers, but also as communist party workers. Writers like Maha Shweta Devi (Hazar Churashir Maa, Sarsatiya, Chetti Munda O Tar Teer etc.) demonstrated that caste struggle and class struggle were identical in the context of village society. Samaresh Basu (Oder Bolte Dao, Siddhanta, Ganta byo, Mahakaler Rather Ghora etc.) viewed the Naxalites as lost, violent youths driven by irrational passions while Sunil Gangopadhyay (Kendrobindu, Payer Talar Mati etc.), Samaresh Majumder ( Kalbela), portrayed the era in more positive light. Nabarun Bhattacharya (Herbert) shows how it can inspire a person to dream and protest in the midst of all human helplessness. Some of these above - mentioned works got a life on screen by the directors like Gautam Ghose (Kalbela, 2007), Govind Nihlani (Hazar Chaurasi ki Maa, 1998), Suman Mokhopadhyay (Herbert, 2005).

Rabindra Ray, in The Naxalites and their ideology (1988), speaks of a dualistic character of the Naxalite movement, comprising two ideologies - theliterate and existential. There are two approaches to the literate ideology of the Naxalite movement. One of them rests on the idea of poor and landless peasants fighting for political power. The other approach views the Naxalite movement as a socio- economic one arising as a response to the exploitation and subjugation prevalent in the semi -feudal and semi- colonial, socio -economic structure (Ray: 1988).

Almost all Bengali movies related to the Naxalite movement describe the urban youth movement, ratherthan the peasantry; but some Hindi movies have shown the peasant struggle (Kanchan Sarkar). The Naxalite struggle forms the backbone of two contemporary cinematic arguments. From the bipolar demarcations of revolutionary ideology we have witnessed a gradual concurrence of fluidity between unfixable significations (Dibyakusum Ray).

Saikat Maitra \&Samrat Sengupta(2012) in his essay through a reading of the Bengali film 'Herbert'directed by Suman Mukhopadhyay and released in 2006, attempts to understand how and in what forms extremist resistances 
are still a part of our global millennial of perpetual peace. The movie 'Herbert' renders un-avoidable thinking of the Naxalite movement in our times.

A film, unlike some other individualistic art form, needs more means, resources and considerable as semblance of like -minded people, which probably caused to produce a very small member of films, directly depicting Naxalite movement, in comparison to other branches of art, like literature and music. Indian Communists never seriously developed the use of film as apolitical medium. In certain films by individual directors like Satyajit Ray.

\section{Bengali Cinema}

Satyajit Ray which capture the milieu of the 1960's and 1970's, but in different ways are: 'Pratidwandi(1970), 'Seemabaddha' (1971) and 'Jana Aranya' (1975). While Pratidwandi and Jana Aranya are based on the struggle of middle class families,Seemabaddha, is a story of corporate ambition and culture with an allusion to revolutionary politics. Ray points out that unemployment is the prime cause of social unrest and this diagnosis ultimately forms the basis of the similarity of these three movies.

Mrinal Sen's three films: Interview (1970), Culcutta 71 (1972) and Padatik (1973). While Interview and Culcutta 71 depict the objective condition of the movement, Padatik raises some very important questions on revolutionary politics.

Buddadeb Das Gupta's three movies : Duratna (1978), Grihayuddha (1982) and Andhi Gali (1984) and Govind Nehlani's Aakrosh (1980) is relevant for realizing the exploitation of the poor and the dalits, and the nexus among different institutions of state power, while in Hazar ChaurasikaMaa(1997), the significance lies in the state atrocities perpetrated on the Naxalites.

Asok Biswanathan's movie Sunya Theke Suru (1993) begins at the Naxalite movement at early 1970s and then moves forward to early 1990's.

Brtya Basu's Tara(2010)is made on the recent Maoist activities in Jungal Mahal area of West Bengal, its inner contradictions, and atrocities by a Leftist state on the Maoists. Contradictions among the Maoists on the annihilation of poor police constables are discussed.

\section{Hindi Cinema}

TheNaxalites (1980)by Khwaja Ahmad Abbas, Lal Salaam:Revolution is Always Written Blood(2002) by Gaganvihari Borate, Hazaaron Khwaishein Aisi (2005) by Sudhir Mishra,Red Alert; the War within (2010) by Ananth Narayan Mahadevan.Ajay Benerjees'Sopan (1994) reminds the killing of Saroj Dutta at Maidan by the police. The movie shows the nexus among the media, police and the celebrities. Satarupa Sanyals'Anu (1998), a better film,explores the turbulence in the relationship among Sujata, an ex- Naxalite, released from Jail,his love Ananya (Anu) and Sugata's former comrade Bharat. Suman Mukherjees'Herbert (2006) is a story of an individual: Herbert Sarkar, an orphan, growing up in a joint family, running errands for the family members, ill-treated by cousins. The movie flashbacks into his childhood and adolescence and find his relations with the underground activities of Naxalites.

Chakravyuh(2012) directed by Prakash Jha, it is a social commentary on the issue of Naxalites. In this movie Kabir /Comrade Azad discovering a different reality: The abject helplessness of the rural poor, brutally displaced in the name of development, the fruits of which never reach them; their land, their forest, their water have been snatched by their own Government to allow big business to exploit the area and its people further. As the poverty and desperation rise, so does a cry of anger, giving birth to the Naxalite who believes the only way to counter this is with a gun. Chakravyuh maintains an aggressive cinematic tone with sufficient stock of blood and action to dole, but is nothing more than an average action flick in the grab of relevant cinema (Sukanya Verma (2012).

\section{Malayalam Cinema}

Consequently, when filmmakers in Kerala responded to the Naxalite movement through their artistic manifestations, it was not a shocker out of the blue. Among the movies made in Malayalam, some foreground the political dogma of 
the Naxal activist, while others cloak the ideology under the veil of passive proposition. If Kabani Nadi Chuvannappol by P.A. Backer, Amma Ariyam by John Abraham and Aparahnam by M.P. Sukumaran Nair were some of those prominent movies on Naxalism conforming to characteristics of serious cinema. Ithiri Poove Chuvannapoove by Bharathan, Aranyakam and Panchagni by Hariharan were those clearly meeting the requirements of a popular or commercial cinema (Arya Aiyappan).

\section{Tamil Cinema}

Aspiring to redefine Tamil Cinemas association with reality, a new generation of film- makers brought visual styles from world cinema to the screen. This new sensibility placed a high premium on authenticity, intellectualism and naturism in the visual grammar of a progressive narrative (Kumuthan Maderya 2015) produced independently on low budgets outside of the major studio systems, as a mode of production itself, like the European art film tradition and Latin American Third cinema, alternative Tamil cinema was anti-capitalist (Janet Harbold, 2012).

For instance Sivappu Malli (Red Jasmine, 1981, Ramanarayanan) and Thanneer-Thanneer (Water-water, 1981, K.Balachander) and the Art house production Kann Sivanthaal Mann Sivakkun (Tears Bring Revolt, 1982, Sreedher Rajan) Art house dramas likeEzhavathu Mani Than (Seventh Man, 1982, K.HariHaran) and Veedu (Home, 1987, Balu Mahendra). The political satire Kaani Nilam (Piece of Land, 1996, Arun Mozhi) the silent experimental Pesum Padam (Talking pictures, 1986, Singeetham Srinivasarao).

Thus, Balu Mahendra's opposition to commercialism to retell a true story through Veedu. Hari Harans re-enactment of an actual legal battle in Ezhavathu Manithan and Arun Mozhi's disclosures of Political misdemeanors inKaani Nilamwere all framed by the logic of realism, situating revolutionary as intentionally leftist. As a leftist mouth piece, the revolutionary art films assail against the ideological bankruptcy of capitalism. To solicit the sympathies of audiences, Sivappu Malli and Kann Sivanthaal Mann Sivakkunonly justify insurgency at the final resource of the powerless given their material conditions: a perspective also alluded to at the end of the Thanneer-Thanneerand Oru IndhiyaKanavu.

\section{Significance of study}

Although Naxalite Movement has completed 50 years, most of the studies only focused on the genesis of the Naxalite Movement and its impact on socio-economic aspects. Some studies analyzed the role of newspapers. Some research studies also analyze the Bengali, Malayali, and Hindi cinema on Naxalite movement. However, these studies did not analyze the Telugu cinema on Naxalite movement. Thus, the present study is significant in this context.

\section{Research objectives}

1. To understand the Naxalite movement and their ideology.

2. To depict of Naxalite movement in Indian Cinema

\section{Research Questions}

1. Is Telugu cinema correctly presenting violence and destructions by Naxalites and police? Is any slant?

2. Are Naxalites being portrayed as bad people?

\section{Methodology}

This study was build up on the qualitative content analysis Naxalite centric Telugu movies. There are many cinemas released in every year.But most of these films are commercial action and faction oriented. But some directors from Telugu film industry, worked on bold and real subjects. However,only few of them seemed critically on the Naxalite movement. It was found that four movies had Naxalite centric. Hence those movies were taken for analysis. 
IRA-International Journal of Management E' Social Sciences

Table: Selected movies for research study.

\begin{tabular}{|l|l|l|l|l|}
\hline SL.No. & \multicolumn{1}{|c|}{ Name of the Movie } & \multicolumn{1}{c|}{ Year } & \multicolumn{1}{c|}{ Director } & \multicolumn{1}{c|}{ Producer } \\
\hline 1. & Sindooram (Red) & 1997 & Krishnavamsi & Krishna Vamsi \\
\hline 2. & Encounter (Encounter) & 1997 & N.Shanker & Krishna Gattamneni \\
\hline 3. & Kubusam (Moulting) & 2002 & Dr.L.Srinath & Dr.L.Srinath \\
\hline 4. & Virodhi (Enemy) & 2011 & G.Neelakanta & Anil Meka \\
\hline
\end{tabular}

\section{Plot 1 Sindooram}

The story about how a young man (Brahmaji) in a village who wants to become a police officer ends up becoming a Naxalite.Bulliraju (Brahmaji) is in training to become a police officer. He is hot blooded and has a strong sense of justice. Buliraju is from a small village close to the Godavari River.Chanti (Ravi Teja), Bairagi, Satipandu and others are wayward youth who reside in the same village. They spend their time playing cards, drinking and teasing girls. They are all friends with Buliraju. Few of them are also Naxalites and pass information of the on goings of the village to Naxalites who live in the nearby forest. The Naxalites use this information to fight injustice.Buliraju returns in the middle of his police training to find that the local policemen act more like the henchmen of the rich rather than defenders of the people and justice. When Satipandu is suspected of being a closet to Naxalites and is picked up by the police, Buliraju too is picked up too as he tries to defend his friend. The SI shoots and kills Satipandu and later in a quarrel, Buliraju accidentally shoots the SI.Buliraju is thus branded as a Naxalites and eventually becomes the leader of the group, despite having no interest in Communism/Maoism or Vigilantism. Buliraju brings a different approach to Naxalite movement, as he is more focused on delivering justice to the people rather than spread a communist/Maoist ideology. In a way he turns the Naxalite group into a vigilante group. To the police however, they are all the same, as they have taken the law into their own hands. He becomes a symbol of law and order in the 30 surrounding villages and is seen as a form of alternate government. (https://www.youtube.com/watch?v=UveOcjnKo_E)

\section{Plot 2 Encounter}

Encounter is a Telugu drama, starring Krishna and Roja. Kirshna is leader of Naxalite group and Swarnakka (Roja) is main lead in the group. This Naxalite group is formed to help the poor and protect people who are suffering from bloody politicians. Home minister, Mahankali (Kota Srinivasarao) is behind all culprit politicians. Swanakka warns Mahankali to stop all his anti -social activities. Superintendent of Police (SP) Siddartha (Vinod Kumar) is given full powers to vanish the Naxalite group. Suryam (Ramesh Babu) son of Yellamma (Radhika) who wants to become doctor to serve all his villagers becomes a member of Krishnanna's Naxalite group. (https://www.youtube.com/watch?v=oQsI4iSbvO)

\section{Plot 3 Kubusam}

Hari Prasad (Giri) is a medico, who studied MBBS with scholarships. He wants to repay the system by serving as doctor in remote village though he got a lucrative job in a corporate hospital. He leaves his medico girlfriend Seema (Swapna) and the big bucks to serve poor people in a remote village of Nizam area. That village is infected by feudalism and vandalism. Police, government administration and the landlords join their hands together to rob the poor man and kill those who oppose them. In one such event, Hari Prasad gets hooked in a critical incident and is about to be subjected to the fake encounter by the police. Then Sivaram (Srihari) rescues them. Frustrated by the attitude of administration and police towards the poor, Hari Prasad joins the war group and is made as commander for a sub group with an alias name Sankaranna.In the process, there comes an honest and wily IPS officer Ashok. He is a nice human being, but would not shy away from conning the weaklings in ultras to get his work done. Slowly, he eliminates Sivaram and other key cadre people. (https://www.youtube.com/watch?v=UZGwNmFCXxU) 


\section{Plot 4 Virodhi}

Jaidev (Srikanth) is a journalist whose articles have become bothersome for politician Jangayya (Ahuti Prasad). Obviously the politician tries to woo the journalist who is a touch too idealistic. It is during their conversation that a group of Maoists, led by Gogi (Ajay), attack and kill the politician. They take Jaidev as a protection and cross the city along with him. Heightened security measures from the police, especially after the killing of a politician, mean that Gogi and his group will have to walk most of their way back home to Nallamala forests. It is during their way back that Jaidev, though afraid for his own life, discovers the story of each of the group members which includes Hari (Kamal Kamaraju), Ramakrishna (Ravi Varma), Mallaiah (Sivaji Raja), Gogi's wife Rehana etc. Jaidev's consistently sensible questions begin to bother the mindsets of the group - eventually breaking it. This only makes Gogi even more adamant on killing the journo, but he needs the support of few other team members, especially from Hari, the idealist and the recruiter. Will Jaidev be able to survive through the hardships of living in jungles and almost one person's jungle-raj? (https://www.youtube.com/watch?v=QWeNCqncjiY)

\section{Content Categories}

For the purpose of this study, the researchers made five categories, i.e.1. Violence and destructions, 2.kidnapps and torture 3 .Encounters and fake encounters, 4.Use of Adivasi's /Coverts for information, 5.Punishments in Public Courts/ Lock up. In this each subject category researchers observed two sides i.e. a. Naxalites side, b. police side.

\section{Violence and Destruction}

a) Violence and Destruction by Naxalites: Ambush and landmine blasts, Government and private (Class enemies) property destruction.

b) Violence and Destruction by Police: Innocent people murders by police, Adivasi properties destructed by police on the name of combing operations.

\section{Kidnaps and Torture}

a) Kidnaps and Torture by Naxalites: Politician, police, official's informers, covert kidnaps.

b) Kidnaps and torture by Police: Kidnaps of innocent people, family members of Naxalites, Human Rights Activists.

\section{Encounter and Fake Encounters}

a) Encounters initiated by Naxalites

b) Encounters initiated by police

\section{Use of Adivasi's /Coverts for information}

a) Naxalites use Adivasi peoples as informers and couriers.

b) Police use Adivasi/surrender Naxalites as police informers and coverts.

\section{Punishments in Public Courts/ Lock up}

a). Naxalite punished the police informers and land lords in Public Courts

b) Police punished the Adivasi and caught Naxalites in lock up

Directors of those films are very well focused on the Naxalism and Police System from all sides. The above perception have been drawn from these movies.

\section{Violence and Destruction}

The selected films are very well focused on the violence in both sides i.e. Naxalites as well as police. In the movie of Sindooram the Naxalite leader Chandram (Surya) is bleeding to stop the police incidents in the village. Police are killing the Naxalite leader Gopalreddy (Narasimharaju) with the name of culling and peace-keeping conservation. In 
this way, local doctor Shekhar was also fake encountered by police to cooperate with the Naxalite movement. In the same way villagers encounter Bairagi and Sattipandu by the police. The common people are shot in the guns between the police and the Naxalites in villages in order to capture the Naxalite leader of Bulliraju (Brahmaji).

In the movie Kubusam Naxalites are raid on police station and shoot at police and grab the guns. In Encounter movie, the police come in to the villages and villagers are beaten to find out where about the information of Naxalites and some people are taken into custody. In turn, the Naxalites are attacked by police. In Virodhi movie the corrupt minister, Jangayya (Ahuthi Prasad), was killed by Naxalites along with police. In this scene ordinary people has died along with police.

Destruction is well shown in the selected movies. In Sindooram, the film starts with destruction. Naxalitesunder the leadership of Chandram (Surya) blown up by land mine a vehicle carrying police constables from the election duty. In this incident, ten innocent police constables were killed by Naxalites. The Police Station was blown up with land mine by Naxalites to prevent police atrocities in the village. Similarly, in Kubusam movie Naxalites Leader Shivaram (Srihari) led the minister convoy while bombing. In Encounter movie Naxalites attack on police station and blown up police camp under the leadership of Krishnanna (Krishna). In Virodhi movie is not shown any type of destruction.

\section{Kidnaps and torture}

Kidnap is the strongest weapon of the Naxalites to accomplish demands and problems. In Virodhimovie, Journalist Jayadev (Srikanth) kidnapped by Naxalites and held hostage to protect ourselves. Similarly, in Sindooram movie the Minister (Chalapathirao) was kidnapped by the Naxalites,for demanding the release of informer Byraagi from the police. In Kubusam Ashok (IPS Officer) who is the key officer in Naxalite culler was kidnapped by Shivanna (L.Srinath). In Encounter movie Minister Mahankali (Kota Srinivasarao) was kidnapped by Naxalite leader Krishnanna to protect the Medico Suryam (G. Ramesh). Finally, Minister was killed by Kirshnanna.

\section{Encounters and fake encounters}

It is a false notion that the Police have patent rights on Fake Encounters. Many innocent people are died in fake encounter in the name of Naxalites. The selected movies directors are well discussed about the fake encounters. Sometimes Naxalites are also killed the policemen and politicians.

In Kubusam movie, the Naxalite Leader Shivanna has encountered the MLA and police officer Subash, whoharms the poor farmers. Shivana kills that surrendered Naxalite Gangaram act as police informer to sending their secrets to the police. Police Officer Tyagi is also murdered by the Naxalites. Similarly in Encounter movie Naxalite woman leader Swarnakka was encountered by the SI (Jeeva). The Police constable Raheem (Chandra Mohan) questioning the act of fake encounter of medico Suryam and others by the SI, in this scene SI was shoots Raheem by a gun. In Sindooram movie Doctor Shekhar was encountered by the police allegedly, he helps to Naxalites.

\section{Use of Adivasi's /Coverts for information}

In the selected films were very much discussed for use of Adivasi's for catch the Naxalites by the Police and the Naxalites also use informers to know about the police and other political leaders moments.

In Virodhimovie, Industrialist Ajit Kumar for his own benefit, he has provided information about the political leaders to the Naxalite leader Gogi (Ajay). Gogi was fake Naxalite leader. In Kubusam movie Police Officer Ashok succeeds to catch the leader Sivaram and he know about the Naxalites activities with the help of the Chandranna. Similarly in Encounter movie Medico Suryam helped to Naxalite Leader Swarnakka to cross over from the city. Police used villager Yadaiah to catch Naxalite leader Krishnanna.In Sindooram Dr. Shekhar is sympathetic to Naxalites.

\section{Punishments in Public Courts/ Lock up}

There are several incidents accrued in the society. The same has been reflected in the movies or media. The selected movies are well focused on those issues. 
In Virodhi movie industrialist Ajit Kumar is caught by police for giving information to Naxalites. Similarly, Sindooram movie the landlord was stripped by the Naxalites that was forced to take the land from poor people. Police arrested Bairagi (Paruchuri Venkateswararao) as the Naxalites are cooperating. In Kubusam movie the Panchayati president was stripped by the Naxalite leader Shivaram . In Encounter movie the villager (barber) has punished by Dora (Prasad), the reason is barber has not attended in time to shave Dora. At that time Leader Krishnanna has entered and punished Dora. Medico Suryam harassed by Police doubted as informer of Naxalites.

\section{Findings and Discussion}

Sindooram has made strong opinion build on the Naxalite movement. The people who face problems and suppression of day-to-day life. In this reason the people are attracted towards Naxalism very much focused in this film. Gopal Reddy (Narasimharaju) character represents a strong ideological Naxalite. But, Chandram (Surya) character believes action for reaction is the moto of the Naxalismto show the struggles and difficulties of the Naxalite Informers. At the same time the commitment on the movement is well shown through Sattipandu and Bairagi (Paruchuri Venkateswararao) characters. The director is well focused, how the people face problems by the police and atrocities of the public by the state. Naxalism is the only way to provide parallel justice for the society. The movement has been deviated from their objectives of the Naxalites well focused in the film through Naxalite leader Chandram character. Overall the soul of the movie, if any ideology is not responsible for the community and valueless it does not survive.

The director of Encounter N.Shankar has done very well with the fact that the Naxalites movement from the police violence. It shows how well the students are attracted towards Naxalite movement through the Encounter movie. The film has been shown all phases of the Naxalite movement. Particularly, very much screened the fake encounters by the Police Department. The importance of the women activist for the Naxalite movement well showed in this film through the character Swarnakka (Roja).The anarchy of the policemen is shown by how the common man, particularly students are deprived of their lives. It's well established in the movie through the character Medico Suryam (Ramesh).How families of the students suffered is very much shown through the character Mallamma (Radhika) mother of Suryam. Especially in the scene of Swarnakka encounter, the scene that the parents announce do not know her, because they are afraid of the police. In this particular scene is mirrored to the present situation. The film highlighted the Naxalite movement's values and commitments to the public well spoke by the character Krishnanna (Krishna).The director create good opinion on Naxalite movement but the police are culprits.

About the Naxalite problems and Naxalite movement is well discussed in the filmVirodhi. The director very much pointed out that the theoretical changes in the movement. Minster Jangiah's (Ahuthi Prasad) character indicate that the political leaders are corrupt. The role of the journalist to the society for highlighting in the movie through the character of the journalist Jayadev (Srikanth). The director's thoughts reveal the real Naxalite can be seen by the Hari character. When it touches the movement and the people, who has come in to the movement with the shortterm benefits and selfish ideas focused through Gogi and other characters. In the climax scene in the movie, thus in the conversation between Journalist Jayadev (Sirkanth) and Naxalite Hari (Kamal Kamaraju). Jayadev says toHari "neeku siksha padkunda nenu chusukunta longipo, neeku manchi jaruguthundhi" (I will take care of you and not be punished, and you will be good ) in reply to this Hari says " sikshaku bayapadevadni aithe ikkadaku rannu, naaku naa manchi kanna samajam manche kaavali”( if I am afraid, I don't come here, I want good of society not mine.) . In the scene, the director pointed out that the real Naxalite ideology is always committed towards the society.

Kubusam is only movie to establish the strong good opinion of the Naxalite movement. The Director has succeeded that what says to the public through movie, to said that without any unrealistic and fiction and commercial elements. $\mathrm{He}$ said straight forwardly. In this movie very much focused pros and cons of the Naxalite movement. The director's questioned that to be good to the people why are in the forests? By the Gangaram character and to do good to the people not possible in the outside of the forest (Society) told by Hari character. The Director answered the questions that arise among the people. The entire movie shows that the Naxalite movement is not killing or not to die, it was the help to the society. Naxalites are work for the indiscriminate society. 


\section{Conclusion}

From this study it is observed, the present phase of Naxalism has no class war as its basis and is mainly directed against the police and Government for in self-defense. Previously, the highly educated youth have been largest supporters/members of the Naxalite movement. Today, victims of money lenders and land lords, as well as poor people think that Naxalism can provide solution their problems and they join in Naxalite movement. Consequently, the movement which has strong ideological base and due to lack of commitment that seems to have shifted away from it many of them could not adjust the life of Naxalite and they are leave the movement in very short period. After they are acted as police informers and the surrendered extremist are turning into a black murderous gangs leading land mafia, settlements and extortion racket with help of police. Some women Naxalites were sexually exploited by the some superiors of the movement. The above dirty activities are done by them those who have come in to the movement with the short-term benefits and selfish ideas.

Similarly, in the view of the police and politicians, the problem of Naxalite movement is only the problem of law and order. Whereas, for the Naxalites, Naxalite movement is not a problem, but the solution to the problem. According to them the real problems areviolation of democratic rights, deep- rooted poverty, landlessness, hunger, joblessness, rising debts and suicides growing bankruptcies and it devastation, and state terror and black murderous gangs and the rising inequalities.

Naxalites are revolutionaries not terrorists. Terrorists are against the Country but Naxalites are against the corrupted system. The films attempt to engage with the Naxalite terrorist debate. Which itself the central theme of the films it tries to break the myth that Naxalism is Terrorism and that the Naxalites, in particular CPI (Maoist) employ terror as political instrument and that is not a political movement. In this context many such movies can be produced and directed to impress society that Naxalism is trying to drive the point of failures of the governments to eradicate poverty and show Naxalites are not terrorists or anti-social elements.

\section{References}

[1]. Arya Aiyappan (2012) Thalappavu: When the Ghost Haunts the Conscience. ed.Pradip Basu, Red on Silver: Naxalite in Cinema. Setu Prakashani.

[2]. Burns, T. 2015. 'Marxism and Science Fiction: the Case of The Matrix', in E. Mazierskaand .

[3]. A. Suppia (eds), Red Alert: Marxist Approaches to Science Fiction Cinema. Detroit, MI: Wayne State University Press.

[4]. Dibya Kusum Ray(2012). The Ideological and the Existence: Naxalite Ideology in Hazaaron Khwashein Aisi and Herbert. ed.Pradip Basu, Red on Silver: Naxalite in Cinema. Setu Prakashani.

[5]. Janet Harbold (2012) Film Cultures. London: Sage, 43.

[6]. Kanchan Sarkar (2012) Naxalite movement and Indian Cinema: A political Analysis. ed. Pradip Basu, Red on Silver: Naxalite in Cinema. Setu Prakashani.

[7]. Kendrik, J. 1999. 'Marxist Overtones in Three Films by James Cameron', Journal of Popular Film and Television 27(3): 36-44.

[8]. Kumuthan Maderya (2015) Red flags in Tamil Cinema : Agitprop and Art house during the cold war. Historical Journal of Film, Radio and Television, Routledge.36:1, 68-87, DOI:1080/01439685.2015.1134110

[9]. Madhu Babu. J. (2010) Newspapers and Naxalite Movement: Kanishka Publishers, New Delhi.

[10].Rabindra Ray (1988) the Naxalites and their Ideology, Delhi, Oxford University Press

[11].Saikat Maitra \& Samrat Sengupta (2012) The other side of Spectacle in Herbert : Return of naxalbari or the Haunting of an Inescapable past? ed. Pradip Basu, Red on Silver:Naxalite in Cinema. Setu Prakashani. 